\title{
Defining a Democracy: Reforming the Laws on Women's Rights in Chile, 1990-2002
}

\author{
Merike H. Blofield \\ Liesl Haas
}

\begin{abstract}
This article evaluates 38 bills seeking to expand women's rights in Chile and finds that the successful ones often originated with the Executive National Women's Ministry (SERNAM), did not threaten existing definitions of gender roles, and did not require economic redistribution. These factors (plus the considerable influence of the Catholic Church) correlate in important ways, and tend to constrain political actors in ways not apparent from an examination of institutional roles or ideological identity alone. In particular, the Chilean left's strategic response to this complex web of interactions has enabled it to gain greater legislative influence on these issues over time.
\end{abstract}

The majority of Latin American countries have now been formal 1 democracies for at least a decade, and the focus on democratization per se has given way to a concern with the quality of democracy and the determinants of democratizing political change. Roberts (1998) argues for conceptualizing democratization, or the deepening of democracy, as a "process," not an outcome, and calls for research efforts on the wide range and myriad permutations of political systems falling under the rubric of consolidating democracies. Legislation dealing with women's issues is an ideal focal point for this type of analysis, especially in Latin America. By looking at attempts to promote women's equality, we can examine a government's political responsiveness to the enhancement of equal rights for all citizens, arguably an essential aspect of deepening democracy itself.

Institutional studies, as well as those focusing on ideology and values, are the basis for our examination of how these factors interact in the specific policy area of women's rights. This article argues that an analysis of both institutional and political and ideological factors is essential to understand fully the political process and outcomes for political and social reform, in this case women's rights. This study examines the varying success of the 38 bills seeking to expand women's rights that were introduced in Chile between 1990 and 2002.

Chile is an ideal case for analyzing these issues: its nondemocratic institutional structure and anachronistic legal framework governing the 
rights of women coexist with a women's movement pressuring for change and left-wing parties willing to take up the challenge. At the same time, the relative stability of posttransition politics and the continuity of the political balance of power between 1990 and 2002 provide an opportunity to analyze variable legislative success in this policy area over time, within an institutional structure offering both incentives and obstacles to legal reform on women's rights. This study analyzes the interaction of ideological and institutional factors that help to shape women's rights legislation and evaluates evolving efforts by the left to gain greater influence over social policy in this area. The 38 bills reveal a wide range of proposals, covering issues of health, education, labor, the constitution, and foreign relations. This variety gives us the confidence that our findings capture some broad and general trends in relation to women's rights.

The bills are analyzed according to the construction of gender in each proposal, the extent to which the bill would require economic redistribution by the state, and the bill's institutional branch of origin. The analysis concludes that the most successful bills tend to be those that originate with the Executive Branch's National Women's Ministry (SERNAM, Servicio Nacional de la Mujer), do not fundamentally challenge existing definitions of gender roles, and do not require redistributive functions on the part of the state. While each of these factors is important in explaining the variable success of women's rights legislation, the factors also correlate in important ways. The politics behind attempts to reform laws on women's rights in Chile can be understood only by looking at their interrelationship. Political actors are constrained in ways not apparent from an examination of institutional roles or ideological identity alone. The left's strategic response to this complex web of interactions, moreover, has enabled it to gain greater legislative influence on these issues over time.

\section{Conceptualizing Policy Reform ON WOMEN'S RIGHTS}

Support or opposition to reform on women's rights is only partly linked to the economic left-right dimension. It also relates to deeply held beliefs about women's roles in the family and their participation in society. Conservative discourse tends to characterize the traditional family and the different social roles of men and women in it as the natural, complementary outgrowth of the biological differences between women and men. Conservative social and political actors therefore oppose proposals that aim to rebalance this traditional structure.

Feminist research, by contrast, focuses on how traditional conceptions of the family put women at a disadvantage (for example, through 
women's double labor burden, their social and legal inequality in marriage, and their economic dependence on men). For this reason, feminists often frame their arguments in terms of women's individual rights and the primacy of those rights over the socially constructed obligations connected to the roles of wife, mother, and so on. These arguments are often reflected in policy proposals by the left (and to a lesser degree, the political center).

Scholars have sought to characterize the nature of this debate. One of the earliest attempts to do so was Molyneux's famous distinction between "practical" and "strategic" gender interests (1985). She identified practical gender interests as those that sought to make women's situation better within their traditional gender roles (for instance, feeding their infants); strategic interests were those that sought to transcend women's traditional roles. These categories overlap somewhat, and it is impossible objectively to draw a definitive line between them; but it is this basic dynamic that other scholars have identified when seeking to improve on the characterization. On the macro level, scholars of public policy in welfare states distinguish between social rights attached to the individual and rights based on a woman's family relationships and marital status (see, for example, Esping-Andersen 1990; Sainsbury 1994, 1999; Hobson and Takahashi 1997; Lewis 1997; O'Connor et al. 1999; Mazur 2002; Huber and Stephens 2001). Norton (1999) identifies a separate gender dimension in a quantitative analysis of legislator votes in the U.S. Congress, although she does not give this dimension a name.

Proposals to improve women's lives can be articulated in traditional discourse or framed in terms of women's individual rights. For example, Pickup's (2001) global study of domestic violence legislation distinguishes between "rights-based" laws, which view women as individuals, and laws based on traditional conceptions of women's social roles. Many theorists argue that framing women's needs in traditional discourse has not been particularly beneficial for women (see, for example, Sen 1999 in relation to gender and development).

At the heart of these categorizations is the distinction between the traditional conception of women's identity (as inseparable from their role in the family) and the contemporary society-centered and individual-rights conception. For the purposes of this analysis of legislative bills, this distinction is characterized here as role-based versus rightsbased claims. Role-based framing seeks to better women's situation in a way that does not threaten a woman's role as wife and mother in a traditional conception of the family. An example of this is a bill that allows working women to take breaks to nurse their infants or ensures homemakers access to health insurance through their husbands' employment. A rights-based framing seeks to extend individual rights to women. Such framing explicitly recognizes women as independent adults. An exam- 
ple of this is a bill that seeks to equalize the property rights of women and men in marriage or guarantees legal abortion as a woman's right to control her body. In some instances, role-based framing may indirectly or directly enhance women's rights as individuals as well; however, the categorization of legislative bills in Chile focuses on the primary, or explicit, aim of the proposal.

Reform in legislation on women's rights has progressed at an uneven pace across the world. Democratic political settings have been most conducive to it; in these settings, local social and political configurations have influenced the ability of feminists and reformers to garner the necessary political support for reform. The role- and rights-based claims of feminists and reformers tend to be shaped by where such distinctions lie in the dominant religious and social traditions of specific countries.

In the Western world, the major distinction in framing and content of women's rights bills is between majority Protestant and majority Catholic countries, although proposals that require significant redistributive outlays (for instance, cash transfers to single mothers) are more generous in Social Democratic and Christian Democratic welfare states than they are in Liberal welfare states (for a review of these distinctions, see literature cited above). Siaroff (1994) categorizes countries such as Spain and Portugal as "late female mobilization states" because of their recent military regimes, the political salience of the Catholic Church, and their status as less-developed welfare states. The more advanced countries of South America, Chile, Argentina, and Uruguay, fit into this category as well, although their welfare states are distinctly less extensive than those of Southern Europe. In all these states, explicitly anticommunist authoritarian regimes sought to undermine the left and to reinforce class privileges and the institutional power of the Catholic Church. They not only froze reform on redistributive issues but also put a stop to secularization of legislation and reform on women's rights.

In this environment, attempts to promote social reform that surfaced during democratization were likely to encounter both class- and religious-based opposition. One factor favoring reform on women's rights was the lag between passage of laws on women in these countries and the global evolution in women's rights. Since the 1950s, Catholic teaching has recognized as legitimate women's need to combine motherhood with paid work outside the home. Similarly, the church no longer supports explicit legal discrimination against women as property owners. This meant that sex-discriminatory civil and criminal codes, many of them enacted in the nineteenth century with Catholic doctrine in mind, were, in the late twentieth century, no longer in accord with Catholic teaching on the family.

Conservative opponents of reform on laws and policies toward women therefore could not unequivocally count on the support of the 
Catholic Church. On some socioeconomic issues, moreover, conservatives have found themselves on the opposite side of the debate. This is partly because contemporary Catholic social doctrine translates uneasily into traditional left-right political distinctions. On a number of social issues, including support of a living wage and opposition to capital punishment, the church situates itself politically to the left of center. At the same time, the church's "prolife" philosophy also extends to a defense of traditional gender roles, conceptions of the family, and norms of sexual conduct, which correspond closely to the positions of the political right.

Democratization offered reformists the opportunity to take advantage of renewed civil and political rights and to demand change in discriminatory legislation. Legitimating moral discourses no longer existed to defend some of the most archaic legislation. Those opportunities came with strict limits, however, depending on the Catholic Church's political importance and, accordingly, reformers' ability to frame bills that complemented rather than conflicted with the church's position. With regard to women's rights, this meant "role-based" framing that did not threaten Catholic conceptions of the family and sexuality.

In countries such as Spain, Portugal, Uruguay, and, to a lesser extent, Argentina, the decreased political salience of the Catholic Church has allowed for a broad range of gender-related reforms since the transition. ${ }^{1}$ In the specific case of posttransition Chile, however, both religious and class-based opposition to reform is strong. The Pinochet dictatorship (1973-90) had retained the status quo on extant legislation that discriminated against women and had even outlawed therapeutic abortion in 1989. During the transition, the Chilean women's movement began to call for reform on such laws. The left's receptiveness to such proposals-particularly those that touched on sexuality and definitions of the family-provoked the church into renewing its efforts to influence political debates in posttransition politics. The church had gained such influence through its legacy as a human rights supporter during the military regime and the increased moral leverage this provided.

With the democratic transition, the church attempted to parlay its increased visibility and the respect it had earned as part of a democratic opposition into political influence over the policymaking of democratic governments (Fleet and Smith 1997; Pollarolo 1997; Haas 1999; Aguiló 2001). The prioritization by Pope John Paul II (1978-2005) of issues related to sexual morality and the family also resulted in a shift in focus in the church hierarchy, which increased the pressure on Christian Democrats to avoid reforms on these issues (Blofield 2001). ${ }^{2}$ The political implications of this pressure were significant, given that the Christian Democrats, a party with philosophical and historical links to the church, were the largest party in Congress and controlled the presidency 
from 1990 to 2000. Since 2000 (and until 2006) the presidency has been in the hands of Socialist Ricardo Lagos.

In addition, Chile has a strong and well-organized political right, which opposes policies that threaten both class privileges and Catholic moral teaching. Since 1973, the right's power has increased not only politically but structurally. The top quintile of the population increased its share of wealth from 52.3 percent in 1971 to 62 percent in 1994 (Deininger and Squire 1996). This trend, along with massive privatizations of formerly state-owned corporations, social security, education, and health care programs, has concentrated economic power in the hands of a small and extremely powerful elite, represented by the right. On the other hand, the global weakening of the left during the 1980 s and 1990s, the repression of political leftists and left ideology during the military regime, and pressure on the left to accept the basic tenets of Chile's economic model as a precondition for forming a coalition with the Christian Democrats have eliminated attempts by the parliamentary left to propose radically redistributive bills in Congress. ${ }^{3}$

\section{A TYPology OF Women's RigHTS LEGISLATION}

The 38 bills considered here vary considerably in terms of the scope of the proposals and the consequent degree of political controversy they can be expected to provoke. Two relevant underlying dimensions can be identified: an economic dimension and a specifically "gender dimension."

To examine the nature and probable success of different types of bills, this study created a fourfold typology based on gender and class. The distinction along the gender dimension is whether a bill is rightsbased or role-based. Along the class dimension, the distinction is whether a bill requires redistributive functions on the part of the state and thus threatens existing class privileges. The bills are classified on the basis of content, without regard to the ultimate success or failure of the proposal. (We also recognize that clear lines on some of these issues are difficult to draw and may be subject to disagreement.) This categorization serves to illuminate the underlying dynamics of women's rights legislation in Chile in a more broadly comparative perspective and to draw out the gender dynamic identified in the comparative feminist literature.

In addition to the content of the bills, each proposal's governmental branch of origin is noted. The legislative power of the executive branch has been identified in the literature as a major influence in the policymaking process (Baldez and Carey 1999; Siavelis 1999, 2000). The legislative role of the executive is a major factor in Chile across legislative areas, and particularly in the area of women's rights, for which a National Women's Ministry (SERNAM) was created in 1990. As part of 
Table 1. Passage Rate of 38 Bills by Content and Institutional Origin

\begin{tabular}{lcccc}
\hline \hline Content of Bill & $\begin{array}{c}\text { Origin: } \\
\text { Congress }\end{array}$ & Passage & $\begin{array}{c}\text { Origin: } \\
\text { SERNAM }\end{array}$ & Passage \\
\hline Role-based/nonclass & 5 & 3 & 3 & 3 \\
Role-based/class & 4 & 2 & 2 & 2 \\
Rights-based/nonclass & 15 & 1 & 5 & 3 \\
Rights-based/class & 3 & 0 & 1 & 1 \\
\hline \hline
\end{tabular}

the executive branch, SERNAM has been active in introducing legal reforms in women's rights.

While the overall number of cases is low when dealing with concerns of statistical significance of the relationship we find here, a few trends can be observed (see table 1). First, in terms of content, relatively few women's rights bills challenge existing class privileges or require significant redistributive functions from the state. Less than 30 percent of the bills fall into one of the class categories. Second, on the gender dimension, more rights-based bills than role-based bills have been introduced, but rights-based bills have a lower rate of passage overall. This is most notably the case with bills that originate in the congress. Finally, branch of origin appears to be a crucial factor in the successful passage of the bills. SERNAM has introduced fewer bills than have legislators, but these executive-sponsored bills have a much higher rate of passage.

The formal and informal powers afforded SERNAM as part of the executive branch give it an edge in policymaking over congressional representatives. At the same time, SERNAM has taken a more conservative approach to many of these topics than have left-wing representatives in the congress, and more moderate bills have a greater chance of passage. While the SERNAM'S relative conservatism has been noted in existing research (Waylen 1996; Valenzuela 1999; Baldez 2001; Htun 2003), an as-yet unexamined aspect of this process is the attempt by the left, led by feminists in the parties, to respond strategically to this situation. The relative success of role-based bills and of executive-sponsored bills, however, points to the influence of both ideological and institutional obstacles to greater left influence over policy.

\section{The Influence of Polrtical Institutions}

Formal and informal institutional factors affect the dynamics of interbranch and interparty relations in Chile, and these factors shape the legislative options available to the left to influence policy. The Chilean Congress includes five major political parties. The governing Concertación coalition is controlled by the centrist Christian Democrats (PDC) and the 
two main leftist parties, the Socialist Party (PS) and the Party for Democracy (PPD). The far-right Independent Democratic Union (UDI) forms an alternative electoral alliance with the other major right-wing party, National Renovation (RN). In the first three democratic administrations, the Concertación held a majority of seats in the Chamber of Deputies, as well as among elected representatives in the Senate. With the inclusion of nine "designated senators," however, the Concertación lost majority influence to conservative senators. Within the Concertación, the PDC has consistently held more seats than the combined parties of the left.

As is evident in table 2, the left, center, and right in Chile have each maintained significant and relatively stable electoral support since the transition to democracy. The electoral law implemented in 1989 transformed Chile's premilitary-regime proportional representation electoral system to one with binomial districts. The new system encouraged the formation of broad electoral and governing coalitions, and the left joined the Concertación, which has governed Chile since 1990. While the coalition has, to date, prevented the right from gaining the presidency, the forced cohabitation of two distinct political ideologies in the governing alliance creates a complicated system of political incentives for the parties. The need for coalitional unity must be balanced against the desire of each ideological faction to have an impact on policy. ${ }^{4}$ With regard to the legislation examined here, this system creates legislative competition between SERNAM and representatives in Congress, along with tension between the left and the Christian Democrats within the Concertación.

\section{Interbranch Competition}

The executive branch in Chile possesses strong legislative powers. Formal executive powers include the ability to determine the legislative agenda for most of the year and exclusive legislative jurisdiction over a number of crucial areas, including budgetmaking. The executive also has the power to declare a bill "urgent," which keeps it alive in committee and encourages congressional debate on it.

Arguably of equal importance in the policymaking process are the executive's informal powers, including considerably greater financial resources than congressional representatives command, and also an extensive legislative staff. This allows executive ministries to develop bills that are often technically superior than similar congressional proposals. In addition, informal procedural rules allow members of the executive to participate in congressional committee meetings. In terms of women's rights legislation, this allows SERNAM to craft a persuasive proposal and to monitor it closely throughout the review process, while the authors of congressional bills are often shut out of the relevant review committees (Haas 2000). 
Table 2. Chile's Elected Representatives,

First Three Democratic Congresses

\begin{tabular}{|c|c|c|c|c|c|c|}
\hline \multirow[b]{2}{*}{$\begin{array}{l}\text { Coalition } \\
\text { and Party }\end{array}$} & \multicolumn{2}{|c|}{ 1990-1994 } & \multicolumn{2}{|c|}{ 1994-1998 } & \multicolumn{2}{|c|}{ 1998-2002 } \\
\hline & $\begin{array}{c}\text { Chamber } \\
\text { of } \\
\text { Deputies }\end{array}$ & Senate $^{a}$ & $\begin{array}{c}\text { Chamber } \\
\text { of } \\
\text { Deputies }\end{array}$ & Senate & $\begin{array}{c}\text { Chamber } \\
\text { of } \\
\text { Deputies }\end{array}$ & Senate \\
\hline \multicolumn{7}{|l|}{ Concertación } \\
\hline \multicolumn{7}{|l|}{ Christian Democrat } \\
\hline Socialist (PS) & 18 & 4 & 15 & 5 & 11 & 4 \\
\hline \multicolumn{7}{|l|}{ Party for } \\
\hline Democracy (PPD) & D) & 1 & 15 & 2 & 16 & 2 \\
\hline Radical (PR) $)^{b}$ & 6 & 3 & 2 & 1 & 4 & 0 \\
\hline \multicolumn{7}{|l|}{ Social Democrat } \\
\hline \multicolumn{7}{|l|}{ Independent } \\
\hline (I-Concertación) & 0 & 0 & 1 & 0 & 0 & 0 \\
\hline Coalition total & 70 & 22 & 70 & 21 & 70 & 20 \\
\hline \multicolumn{7}{|l|}{ Right Coalition } \\
\hline (RN) & 32 & 13 & 29 & 11 & 23 & 7 \\
\hline \multicolumn{7}{|l|}{ Independent } \\
\hline Union (UDI) & 14 & 2 & 15 & 3 & 17 & 5 \\
\hline \multicolumn{7}{|l|}{ Center-Center } \\
\hline $\begin{array}{l}\text { Union (UCC) } \\
\text { Independent }\end{array}$ & 一 & - & 2 & 0 & - & - \\
\hline (I-Right) & 0 & 1 & 4 & 3 & 9 & 6 \\
\hline Coalition total & 46 & 16 & 50 & 17 & 49 & 18 \\
\hline Other & 4 & 0 & - & - & 1 & 0 \\
\hline Congress total & 120 & 38 & 120 & 38 & 120 & 38 \\
\hline
\end{tabular}

${ }^{a}$ In addition to elected representatives, an additional nine senators are appointed. bThe PR and PSD combined to form the PRSD in the second administration.

The legislative strength of the executive can help or hurt attempts to expand women's rights, depending largely on which party controls the government or, in a coalition government, which party controls the relevant ministry (Baldez 2001). SERNAM was headed by Christian Democrats for the first two democratic administrations, and the its centrist political orientation during this time posed both opportunities and challenges to reforming laws on women's rights. 
Tables 3 through 6 illustrate that SERNAM and congressional representatives have introduced a number of similar bills. Executive advantages regarding legislative staff, resources, and access to congressional committees during debates have helped executive initiatives remain viable after similar congressional bills have died. In these cases, the institutional weight of SERNAM has been a key factor in overcoming conservative opposition to the bills in the congress.

At the same time, SERNAM's success also corresponds with bills with moderate content, which also facilitates passage. The Christian Democratic Party's links to the Catholic Church made it reluctant to initiate legislation that would cause conflict with the church. Under the leadership of the Christian Democrats, SERNAM pursued a number of legislative advances for women, but it would not publicly support leftwing efforts to legislate on abortion or divorce, proposals that had support from the women's movement and the public generally but strong opposition from the church. ${ }^{5}$

When the Socialist Party won the presidency-and control of SERNAM - in 2000, the executive began to speak openly in support of divorce legislation. At that point, a conservative version of the latest congressional bill on the topic (Bill 1759) had passed the Chamber of Deputies and had stalled in the Senate. By late 2001, SERNAM began for the first time to apply institutional support to the congressional divorce bill. Conservative Christian Democrats, the right, and the Catholic Church continued to speak out strongly against the legislation.

In sum, while the institutional power of SERNAM has a tremendous impact on the passage of legislation, overall, to date, it has narrowed the range and moderated the content of many of the proposals introduced. The left in Congress has a desire to legislate on these options as well, and it wants more control over the content of the bills. It is therefore critical to consider how much maneuverability the left has within this institutional framework to introduce its own projects.

\section{Interparty Competition and Cooperation}

The Chilean electoral system creates a dual tension for individual parties as they seek to balance the need for coalitional unity against the desire to have their own impact on policy. In the first two democratic administrations (Aylwin, 1990-94, and Frei, 1994-2000), the Christian Democrats held the presidency as well as a plurality of seats in the congress. The party's numerical strength, combined with the formal institutional powers of the executive, gave the party a substantial legislative advantage over the left. Because the party held less than a majority of congressional seats, however, the power of the Christian Democrats was mitigated by the need for left support in the Chamber 
of Deputies and support from both the left and sectors of the right in the Senate.

In addition, the left maintained significant constituent support in Chile, noted both in continuing support for left-wing congressional representatives and in the election of Socialist Ricardo Lagos to the presidency in 2000. With radical economic reforms off the political agenda in Chile (Constable and Valenzuela 1991; Petras and Leiva 1994; Waylen 1993), the left sought to distinguish itself from the Christian Democrats through the development of a distinctive social policy agenda, of which women's rights legislation formed one component. The need for left support in the Concertación afforded the left some opportunity to push for the inclusion of a more liberal policy agenda on issues like women's rights.

Despite being constrained both by the dominance of the executive over policymaking and its own secondary position in the governing coalition, the left has succeeded in influencing policy in this area. The presence of more feminists in the parties of the left than in the other parties, along with the existence of networks of feminist organizations in civil society with their own list of policy priorities, make this policy area a logical one for the left to pursue. ${ }^{6}$

The Christian Democratic Party has publicly expressed its recognition of women's inequality, but at the same time, the party is hesitant to introduce legislation on issues that will bring it into conflict with the church. These factors offer an ideal opportunity for the left to make a unique contribution to the policy process. While this does not imply that all representatives from the left have been highly proactive in introducing legislation in this area, it does mean that, with only a few exceptions, those members of the left who have taken the initiative in introducing legislation on women's rights have been able to count on a solid backing of left support for their efforts.

The diminution of conflict between the Christian Democrats and the left over economic policy reduced political conflict along the class dimension in the Concertación. The shift of the social policy agenda to the private domain and the left's greater willingness to legislate on controversial social issues, however, increased conflict between the Christian Democrats and the left with regard to social policy. It gave rise to intense debates in the coalition over how extensively government policy needed to conform to church teaching, and it caused divisions both within the PDC and between the PDC and the left (Carey 1999; Londregan 2000; Baldez 2001).

Broadly reflecting the social teachings of the Catholic Church, the policy positions of the Christian Democratic Party tend to be reformist on issues of class and conservative on issues relating to sexuality, gender roles, or the family. This implies that if a particular bill causes conflict along the class cleavage alone (assuming that such bills will be moder- 
ate), the majority of Christian Democrats will likely ally with the left against the right. If an issue causes conflict along the gender dimension, however, gaining the support of the Christian Democrats will be more difficult. A solid sector of the Christian Democrats will identify with the right more than the left on such issues (Hinzpeter and Lehmann 1999). ${ }^{7}$

On the other hand, the Christian Democratic Party has become less programmatic over time (Scully 1996), and includes a diversity of opinion on these issues (Londregan 2000; Aguiló 2001; Baldez 2001; Muñoz 2001). This diversity allows for the possibility that a controversial proposal by the left on women's rights, properly drafted, may gain sufficient votes from PDC legislators to pass the congress. The conflict that these issues cause in the PDC means, however, that members of the party will rarely introduce such topics, and winning PDC support for left initiatives will be difficult.

Winning enough support for passage in the Senate is complicated by the appointment of nine designated senators (of 47 total). This gives the right and conservative Christian Democrats more influence over the final form of legislation on women's rights. Left-wing deputies nevertheless have continued to introduce bills on women's rights, arguing that passage by the Chamber may increase public pressure on the Senate to address controversial issues. For example, this has been the tactic used to pass divorce legislation. All but two of the bills on women's rights introduced between 1990 and 2002 were introduced in the Chamber of Deputies.

\section{Political Learning by the Left}

It is precisely these institutional factors that encourage the left to create a legislative program that responds strategically to the opposition to reform on women's rights. The Catholic Church's conception of women's identity is made salient both by the church's cultural influence and by the electoral and legislative strength of the center-right. When crafting a bill on a controversial topic like women's rights, the left needs to consider the potential for the bill's content to cause conflict with the church, because this will ultimately affect the left's ability to build support for the bill beyond the parties of the left. A policy proposal may provoke church officials to speak out against it, as was the case with a number of bills on women's rights, including divorce, abortion, reform of sexual assault laws, and, to a lesser degree, paternity and domestic violence (Grau et al. 1997; Haas 1999, 2000).

Conservative Christian Democrats argue that the party's positions should broadly reflect church teaching. Representatives who adhere personally to church teaching can find it difficult to legislate in opposition to public church statements on an issue. Alternately, conservative 
opponents of a controversial bill may find in Catholic doctrine a legitimating moral discourse for their rejection of reform proposals, a discourse more palatable and politically viable than, for example, the defense of class interests (Palma 1997, 2001; Pollarolo 1997). This latter situation was the case with the paternity bill. Thus, both strategic and sincere opposition to these bills will often refer to church teaching and employ a conservative, "profamily" discourse.

In a political environment where conservative parties are overrepresented and the Catholic Church is an influential force in shaping public discourse on controversial social issues, the left's ability to strategically frame its policy proposals becomes a critical factor for passage. Following its low success rate in passing legislation expanding women's rights in the first administration, and facing the prospect of losing much of the initiative in this area to the (Christian Democratic) executive, the left evolved a conscious strategy of framing bills more moderately, often with the very discourse on women and the family employed by congressional conservatives (Muñoz 2001; Saa 2001).

Specifically, on a wide-ranging number of issues, including domestic violence, day care, paternity, divorce, and abortion, the left began to defend its proposals on the basis of what was good for the family as a whole and what would allow women to fulfill their traditional roles in it (often while they took on additional roles outside the home). The more controversial the bill along either gender or economic lines, the more critical the presentation of the proposal became. It was on the most controversial bills that the left made the most concerted effort to link its support to a concern for the family, arguing that the left legislated for all families, including those that did not conform perfectly to conservative definitions of family and family life.

\section{Owning the Bill}

The left's concern with the scope and content of proposal interacted with its institutional considerations, specifically how much it wanted to control the shape of the bill and how much it was willing to sacrifice authorship for broader political alliance or for executive help in passage. This strategy had potential advantages and disadvantages.

SERNAM sponsorship could help keep a bill alive long enough to build support, but once the left lost ownership of the bill to the executive, it could no longer take political credit for sponsoring the legislation. In addition to sincere support for the issues, the left also wanted to distinguish itself from the Christian Democrats, and congressional representatives preferred not to cede legislative authority to the executive. While the left overall was more supportive of legislation to reform women's rights than the other parties and while women's rights was a 
good issue on which to distinguish itself, the left's political purposes were not served in working hard to get legislation passed if it did not get credit for the initiative.

Once SERNAM took over a bill, furthermore, content changes might be made as part of the negotiations. On the issue of paternity, SERNAM agreed to sponsor a bill after a previous attempt by the left to legislate on the topic failed. In this case, the executive bill was faithful in overall content to the left's original proposal and actually went into considerably more detail on the specifics of the proposed reform. On the issue of domestic violence, by contrast, the left also asked for help from the executive after the left's bill on the subject stalled. SERNAM ended up introducing its own bill on the topic rather than supporting the congressional version. In the public controversy that followed, the executive ceded ownership back to the left but insisted on major content changes, most notably a change from domestic violence to family violence- - which changed the bill's frame from rights-based to role-basedand a reduction of punishment for offenders. The bill eventually became law, but some on the left (and in the women's movement) wondered if the final version were worse than nothing (Matus 1997; Valenzuela 1997; Weber 1997; Haas 2000; Muñoz 2001).

In sum, the trade-off regarding ownership of a bill is that the chance of passage is increased with executive sponsorship, but credit to the left is reduced, as is left control over content.

\section{Rights-based or Role-based?}

Framing an issue as role-based often necessitates content changes that facilitate passage. But analysis of the bills suggests, and interviews with representatives confirm, that the goal behind consciously framing the bills to reflect traditional conceptions about women was precisely to avoid having to make too many concessions on content.

The left's reframing of women's rights issues to incorporate traditional discourse on women did not necessarily persuade congressional conservatives, but it did make it harder for them to use church teaching and "profamily" discourse to justify their opposition. Although the church has well-developed opinions on women, sexuality, and the family, it is often unclear whether a particular bill actually conflicts with the official position. The church's position on abortion and divorce, for example, may be more obvious than its teaching relative to some aspect of a bill on day care, paternity, or domestic violence. Without a unified church position on an issue, the left had more room to frame its proposals. Such framing strategies also provided political cover for legislators who supported the proposals but hesitated to invite conflict with the church. The left, in other words, employed a role-based frame 
on women's issues to try to beat congressional conservatives at their own game.

\section{Case Studies}

An examination of left proposals on women's rights in the first three democratic congresses shows that the left's political strategy in this area evolved, leading to a conscious effort to moderate proposals starting in the second administration (1994-98). This is partly revealed by the sharp increase in cross-party support for the bills at the point of introduction, which also illustrates the left's attempt to build an alliance of support for the bills earlier in the legislative process.

The following sections describe the four types of legislation in more detail, specifying the particular bills on women's rights included in each category. Each bill type is further explained with reference to a particular example of a legislative proposal in each category. Although, for space considerations, discourse is analyzed on only one or two bills of each type, in principle the same qualitative analysis could be conducted on any of the bills. Bills have been chosen that span several policy areas: education, children's rights, family policy, women's health, and definitions of life. The aim is to demonstrate that gaining political support for a bill is not simply a function of the policy area itself but often depends on the definition of women's roles embodied in the proposal, particularly the extent to which the bill's characterization of women complements or contradicts Catholic teaching on women, sexuality, and the family. A secondary dimension that influences political support is the extent to which the bill threatens existing class privileges.

\section{Role-Based, Nonclass BHLS}

Of the 38 bills examined in this analysis, 8 may be classified as rolebased, nonclass-threatening. These bills do not fundamentally challenge existing gender roles or require redistributive measures by the state. On many topics, role-based bills may be interpreted or framed in rightsbased ways as well, and may have rights-based effects. The key is that the explicit aim of the proposal does not threaten either traditional gender roles or class privileges.

The general topics of these bills include protection for abandoned spouses, violence against women, and the education rights of pregnant adolescents. As noted in table 3, six of the eight bills were introduced in the second or third administration. The key determinant here is whether the topics could be framed in a way that did not appear to conflict with Catholic teaching on women and the family. 
Table 3. Role-based, Nonclass Bills

\begin{tabular}{|c|c|c|c|c|c|}
\hline & Topic & Introduced & Sponsor & $\begin{array}{l}\text { Passed } \\
\text { Chamber }\end{array}$ & $\begin{array}{l}\text { Passed } \\
\text { Senate }\end{array}$ \\
\hline Law 19.325 & Family violence & $8 / 21 / 91$ & $\begin{array}{l}\text { Congress: } \\
\text { Left }\end{array}$ & Yes & Yes \\
\hline Bill 499 & $\begin{array}{l}\text { Therapeutic } \\
\text { abortion }\end{array}$ & $9 / 17 / 91$ & $\begin{array}{l}\text { Congress: } \\
\text { Left }\end{array}$ & No & \\
\hline Bill 1251 & $\begin{array}{l}\text { Pregnant } \\
\text { students }\end{array}$ & $7 / 5 / 94$ & $\begin{array}{l}\text { Congress: } \\
\text { Left }\end{array}$ & Yes & Yes \\
\hline Law 19.741 & Child support & $10 / 11 / 94$ & $\begin{array}{l}\text { Congress: } \\
\text { Left-Right }\end{array}$ & Yes & Yes \\
\hline Bill 1515 & $\begin{array}{l}\text { Violence to } \\
\text { women }\end{array}$ & $1 / 17 / 95$ & SERNAM & Yes & Yes \\
\hline Bill 1760 & $\begin{array}{l}\text { Pregnant } \\
\text { workers }\end{array}$ & $11 / 29 / 95$ & SERNAM & Yes & Yes \\
\hline Bill 1759 & Divorce & $11 / 26 / 95$ & $\begin{array}{l}\text { Congress: } \\
\text { PDC/Left }\end{array}$ & Yes & Yes \\
\hline Bill 2202 & $\begin{array}{l}\text { Violence to } \\
\text { women }\end{array}$ & $7 / 14 / 98$ & SERNAM & Yes & Yes \\
\hline
\end{tabular}

\section{Protection of Student Mothers and Pregnant Students}

Date of Introduction: Bill 1251, July 1994.

Fate: Passed the Chamber of Deputies in September 1994 ; Passed the Senate in 2001.

Support: Left: unanimous. Christian Democrats (PDC): unanimous. Right: some resistance, nearly unanimous support by the final vote. ${ }^{8}$

Discourse: This bill was introduced to prevent the common practice of expulsion of pregnant students from school. It originated with female representatives from the left and was jointly introduced by a coalition of male and female representatives from the left, center, and moderate right (RN). It is unthreatening to class privileges, can be easily interpreted as role-based, and is consistent with progressive Catholic social teaching on women and the family.

The bill was attractive to representatives from different parties for different reasons. Specifically because the topic of the bill did not cause conflict with congressional conservatives, representatives from the left felt free to emphasize the rights-based implications of the bill, which prioritized a young woman's right to education. Conservative representa- 
tives saw the bill as a way of dissuading these women from having abortions. These different priorities are clearly evident in statements by representatives during the floor debates on the bill in the Chamber of Deputies. Typical of the position of the left are the comments of Socialist Deputy Isabel Allende.

We know well that if a person interrupts her education, she cannot acquire knowledge or training. Obviously, in this way the cycle of poverty is reproduced for her and for the child yet to be born. ... For this reason, we must not fall into discriminatory practices, by creating obstacles to the completion of her education. ... Furthermore, it seems extraordinarily unjust that only the pregnant adolescent girl is punished by not being allowed to continue her education. This doesn't send a single constructive or formative signal to the boy, who obviously also has responsibility. (Chamber of Deputies 1994a)

The Christian Democrats emphasized both the right to education and the belief that the bill would discourage abortion. One of the bill's PDC sponsors explained that punishing students who become pregnant "goes against the right to education, to personal development, to the formation of that person, and what's more, against something essential, vital, and fundamental: the right of the life yet to be born" (Chamber of Deputies 1994b). By contrast, the right made clear that the primary purpose of the bill was to protect the rights of the unborn. As RN Deputy René García explained,

I am going to vote in favor of this bill because I believe that life has greater rights than education. For this reason, I will support any initiative that favors and provides guarantees that allow a person to be born, since the right to life is the first right that the Constitution ensures, and it begins the moment a life is conceived. (Chamber of Deputies 1994c)

The subject of this bill lent itself particularly well to role-based framing. Support by Christian Democratic representatives (and by most of the representatives from the right) for this left proposal gathered relatively quickly. Few bills on women's rights win cross-party support so easily.

\section{The 1991 Abortion Bill}

Date of introduction: Bill 499, 1991.

Fate: The bill died immediately following its introduction in the Chamber.

Support: Left: official support for the topic of the bill, little explicit support for the bill itself. PDC: unanimous public rejection of the bill. How- 
ever, most Christian Democratic representatives were also opposed to efforts by the right to pass legislation increasing punitive measures against those who have abortions or provide abortions. Right: unanimous rejection. Within the right, there was also broad support for increasing the legal sanctions covering abortion.

Discourse: Therapeutic abortion was legal in Chile from 1936 until 1989, when the military government repealed it in one of its last measures, making Chile one of fewer than a dozen countries in the world that do not allow abortion when the mother's life is at risk. The abortion rate in Chile is high nevertheless, and public opinion has consistently supported relegalization of therapeutic abortion. When a small group of male and female legislators from the left introduced the 1991 bill to do that, immediate and strong opposition arose from the PDC and the right. In response to the outcry, only a small number of left representatives signed on to the bill after its introduction. Instead, the left in general began to distance itself from what it saw as a dangerously contentious bill, one that would not only fail to pass the legislature but also would create tension in the coalition. The topic of the bill, furthermore, directly conflicted with the position of the Catholic Church.

The Chilean Congress has never debated liberalization of abortion laws. ${ }^{9}$ However, the wording of the 1991 bill indicates that the left cast it in entirely role-based terms; it assumes that the women in question are already mothers and focuses on the destructive effect on their children of losing a mother in unwanted childbirth. For example, the bill emphasizes

the numerous psychosocial consequences for children and for the family in general, which result from the loss of the life or health of the mother, which not only destroys a marriage but also implies a traumatic experience for the children, who will suffer a lack of affection because a person fundamental to their formative development ... has disappeared. (Chamber of Deputies 1991) ${ }^{10}$

\section{Role-based, Class Bills}

These bills focus on women's economic rights but are framed in a rolebased way. For example, Bill 1758, introduced in 1995, would allow working women to nurse infants during breaks at their place of employment. Recognizing women as the primary caretakers of children, the bill does not address the need for more comprehensive family leave or affordable day care facilities, but it does attempt to make it easier for women to care for their young children when they must also work in paid employment outside the home.

Six of the 38 bills in the study were assigned to this category (see table 4). They deal with such issues as the rights of domestic workers 
Table 4. Role-based, Class Bills

\begin{tabular}{|c|c|c|c|c|c|}
\hline & Topic & Introduced & Sponsor & $\begin{array}{c}\text { Passed } \\
\text { Chamber }\end{array}$ & $\begin{array}{l}\text { Passed } \\
\text { Senate }\end{array}$ \\
\hline Law 19.010 & Domestic workers & 1990 & SERNAM & Yes & Yes \\
\hline Bill 234 & Domestic workers & $1 / 8 / 91$ & $\begin{array}{l}\text { Congress: } \\
\text { Left }\end{array}$ & No & \\
\hline Law 19.252 & Domestic workers & 1991 & SERNAM & Yes & Yes \\
\hline Law 19.408 & Day care & $9 / 13 / 94$ & $\begin{array}{l}\text { Congress: } \\
\text { Left }\end{array}$ & Yes & Yes \\
\hline Bill 1758 & Child care & $11 / 23 / 95$ & $\begin{array}{l}\text { Congress: } \\
\text { Left }\end{array}$ & Yes & Pending \\
\hline $\begin{array}{l}\text { Senate Bill } \\
2030\end{array}$ & Child care & $5 / 20 / 97$ & $\begin{array}{l}\text { Congress: } \\
\text { Left }\end{array}$ & No & \\
\hline
\end{tabular}

and day care provisions for working mothers. The low number of bills in this category-and in the rights-based class category-suggests the decreased salience of class-based claims in posttransition Chilean politics. As noted, this is not due to a decrease in systemic market-based discrimination, but instead indicates that the political agenda no longer includes significant redistributive measures along the lines of prePinochet Chilean politics or of Western European welfare states.

Because the bills focus on women's economic inequality, they propose some level of redistributive action either from the state or from the private sector. Given this feature, they provoked significant opposition from the right and from an economically conservative sector of the Christian Democrats. However, these sectors were likely to couch their opposition in moralizing, profamily rhetoric rather than in less-sympathetic economic reasoning, and this provided an opportunity for the left to counter the opposition with its own profamily arguments in favor of the bills.

\section{Law 19.408: Limited Day Care Facilities for Women Workers}

Date of introduction: 1994 (introduced in the Senate).

Fate: Passed Senate and Chamber of Deputies in 1995.

Support: Left: unanimous. PDC: unanimous. Right: moderate resistance in the Senate but eventual majority support. Mild resistance in the Chamber, eventual majority support.

Discourse: The 1994 Day Care bill, which became law in 1995, was one of a small number of women's rights initiatives introduced in the Senate. 
Drafted jointly by two members of the left and a Christian Democrat, the bill sought a moderate expansion of an existing law requiring commercial businesses employing more than 20 women to provide day care facilities for their female employees' children on site or to pay the cost for the children to attend a day care center nearby. The bill sought to expand this obligation to include commercial establishments, such as malls, in which the total number of women employed by all the individual businesses was 20 or more. The years since the transition had seen a boom in mall construction, especially in the major cities, and the high overall number of women employed made the lack of child care facilities a chronic problem for families needing to balance work with child raising.

Most of these newly constructed commercial centers were located in the wealthier areas of cities. As part of their efforts to lure shoppers, many malls provided child care for the shoppers' children. In interviews, the authors of the 1994 bill, all members of the left parties, criticized the obvious class bias of these arrangements, in which employers were happy to provide facilities for their wealthy customers but would not allow their largely working-class employees to place their own children in the same centers. In drafting the bill, however, the authors chose not to frame their argument around class bias or women's economic inequality but instead to present the bill as an important support for motherhood.

One of the problems most urgently in need of a solution refers to the protection of motherhood, and specifically the guarantee to establish day care centers for all mothers, even when they labor in an establishment that does not bring together the number of female workers currently demanded by the law. (Senate 1994a)

Because the bill implicitly accepts child care as solely a woman's responsibility, it is framed to reflect rather than to challenge existing gender relations. The bill's authors believed that this approach would facilitate passage, and they argued that the effect of such a law in practice would be to increase women's economic equality (Aguiló 2001).

The role-based framing of the bill, which allowed the left to present itself as a defender of women's roles as mothers, made it politically unfeasible for conservatives to oppose the bill on purely economic grounds. Forced to respond in kind, conservatives framed their opposition in terms of concern for women. A significant sector of the right argued that the bill would end up hurting the very women it was trying to help because broadening the scope of the current law would discourage employers from hiring women. However, the majority of the right, as well as all the Christian Democrats, accepted the role-based arguments behind the bill. As expressed by Designated Senator William Thayer, 
The presence of woman is inevitable in the working world. The solution has to consist in favoring her right to work and giving her the means and guarantees to be able to fulfill her essential maternal obligations, and not in deciding not to hire women in order to avoid having more problems. (Senate 1995)

The conscious decision by the left and liberal Christian Democrats to support the drafting of a role-based version of a day care bill, which required them to set aside ambitions for a more comprehensive reform of the existing law, facilitated the building of conservative support for the proposal. The bill passed both houses of Congress within a year of introduction.

\section{Rights-Based, Nonclass Buis}

These bills, by their very nature, challenge existing gender roles but do not seek redistribution from either the state or the private sector or threaten class privileges. Such bills explicitly seek to expand women's rights as individuals in the family, workplace, society, and politics, and in doing so, seek to rebalance historical gender discrimination. Examples of rights-based bills include equal rights over marital property, laws that prohibit sex discrimination and sexual assault regardless of a woman's background or social status, the earlier divorce bills that identified divorce as an individual right, and electoral quotas for women.

This study classified 20 out of the 38 bills as rights-based, nonclass bills (see table 5). These bills are harder to couch in traditional discourse because they seek to rectify just the kinds of biases that entrenched social and legal norms have produced. However, given the opposition they would provoke from the right and the conservative Christian Democrats, the left did try to do just that. Couching rights-based bills in nonthreatening ways becomes even more important if the right can draw on Catholic doctrine to justify its opposition. When the right cannot do so, it prefers to find ways to bury the bill in committee. In these cases, executive support plays a crucial role in ensuring passage.

The majority of left-introduced bills in this category were unsuccessful relative to role-based proposals. The left wants not only to ensure passage of women's rights bills but also to claim symbolic ownership of issues it believes in, regardless of whether the bills pass or fail. Thus representatives on the left may have incentives to introduce rightsbased bills even knowing they will fail.

A particularly contentious issue, divorce, provides examples of this kind of bill. The early divorce bills sought to secure divorce as an individual right, but the 1995 bill approved by the Chamber, a modified version of which ultimately passed the Senate, made obtaining divorce more difficult (discussed below). For this reason, the 1995 bill, Bill 1759, 
Table 5. Rights-based, Nonclass Bills

\begin{tabular}{|c|c|c|c|c|c|}
\hline & Topic & Introduced & Sponsor & $\begin{array}{c}\text { Passed } \\
\text { Chamber }\end{array}$ & $\begin{array}{l}\text { Passed } \\
\text { Senate }\end{array}$ \\
\hline Bill 197 & $\begin{array}{l}\text { Sex } \\
\text { discrimination }\end{array}$ & $11 / 6 / 90$ & $\begin{array}{l}\text { Congress: } \\
\text { Left }\end{array}$ & No & \\
\hline Bill 302 & $\begin{array}{l}\text { Sex } \\
\text { discrimination }\end{array}$ & $3 / 7 / 91$ & $\begin{array}{l}\text { Congress: } \\
\text { Left }\end{array}$ & No & \\
\hline Bill 355 & Divorce & $5 / 16 / 91$ & $\begin{array}{l}\text { Congress: } \\
\text { Left }\end{array}$ & No & \\
\hline Law 19.335 & Marital property & $8 / 6 / 91$ & SERNAM & Yes & Yes \\
\hline Bill 871 & Sexual assault & $11 / 25 / 92$ & $\begin{array}{l}\text { Congress: } \\
\text { Right }\end{array}$ & No & \\
\hline Bill 953 & Divorce & $4 / 1 / 93$ & $\begin{array}{l}\text { Congress: } \\
\text { Left }\end{array}$ & No & \\
\hline Bill 1048 & Sexual assault & $8 / 3 / 93$ & SERNAM & Yes & Yes \\
\hline Bill 1065 & $\begin{array}{l}\text { Sex } \\
\text { discrimination }\end{array}$ & $8 / 17 / 93$ & $\begin{array}{l}\text { Congress: } \\
\text { Left }\end{array}$ & No & \\
\hline Bill 1090 & Divorce & $9 / 14 / 93$ & $\begin{array}{l}\text { Congress: } \\
\text { Left }\end{array}$ & No & \\
\hline Bill 1189 & $\begin{array}{l}\text { Sex } \\
\text { discrimination }\end{array}$ & $4 / 21 / 94$ & $\begin{array}{l}\text { Congress: } \\
\text { Left }\end{array}$ & No & \\
\hline Bill 1370 & Divorce & $10 / 4 / 94$ & $\begin{array}{l}\text { Congress: } \\
\text { PDC/Left }\end{array}$ & No & \\
\hline Bill 1419 & Sexual assault & $10 / 24 / 94$ & $\begin{array}{l}\text { Congress: } \\
\text { Left-Right }\end{array}$ & Yes & Pending \\
\hline Bill 1579 & $\begin{array}{l}\text { Sex } \\
\text { discrimination }\end{array}$ & $5 / 4 / 95$ & SERNAM & Yes & Yes \\
\hline Bill 1707 & Marital property & $10 / 4 / 95$ & $\begin{array}{l}\text { Congress: } \\
\text { Left }\end{array}$ & No & \\
\hline $\begin{array}{l}\text { Senate bill } \\
1719\end{array}$ & Marital property & $10 / 19 / 95$ & $\begin{array}{l}\text { Congress: } \\
\text { Left }\end{array}$ & No & \\
\hline Bill 1838 & $\begin{array}{l}\text { Sex } \\
\text { discrimination }\end{array}$ & $4 / 18 / 96$ & SERNAM & & No \\
\hline Bill 1994 & Electoral quotas & $3 / 13 / 97$ & $\begin{array}{l}\text { Congress: } \\
\text { Left/PDC }\end{array}$ & No & \\
\hline Law 19.739 & $\begin{array}{l}\text { Age/sex } \\
\text { discriminination }\end{array}$ & $8 / 11 / 99$ & $\begin{array}{l}\text { Congress: } \\
\text { Left }\end{array}$ & Yes & Yes \\
\hline Bill 2667 & $\begin{array}{l}\text { Sex } \\
\text { discrimination }\end{array}$ & $3 / 6 / 01$ & SERNAM & Yes & No \\
\hline Bill 3020 & Electoral quotas & $8 / 6 / 02$ & $\begin{array}{l}\text { Congress: } \\
\text { Left/PDC }\end{array}$ & No & \\
\hline
\end{tabular}


is actually classified here as role-based (see table 3 ). The left moved from rights-based to role-based framing, which succeeded in bringing Christian Democrats on board but also resulted in significant concessions in content. The debates and negotiations that led to legal divorce thereby also serve as an example of intracoalition negotiation.

\section{Divorce Bills}

Date of introduction: Bill 1759, introduced 1995.

Fate: Passed Chamber of Deputies 1997; passed Senate 2004.

Support: Left: official party support; all but one representative voted in favor (one Socialist abstained on religious grounds). PDC: internally divided; 17 of 37 Christian Democrats voted in favor. Right: the official party positions of both the RN and the UDI opposed the bill; on the floor, $9 \mathrm{RN}$ Deputies and 1 UDI representative broke with their parties to support the bill.

Discourse: With the legalization of divorce in Ireland in 1996, Chile became the only major nation to lack some type of legal divorce. Although the Catholic Church grants marriage annulments in specific circumstances, there is no legal way to receive a civil divorce. Divorce a la Chilena refers to the one method of obtaining a civil annulment: committing perjury before the Civil Registrar by claiming that one lied on some aspect of the original marriage license, thereby voiding the contract. Efforts to legalize divorce have focused on recognizing the widespread use of perjury to gain civil annulments and the need to have the state replace this informal system with a set of logical and equitable legal guidelines to regulate the dissolution of marriage.

The left has introduced several divorce bills since the transition to democracy (see table 5), but until 1997, every bill was deemed too divisive to debate. The three divorce bills that preceded the $1995 \mathrm{New}$ Civil Marriage Bill were rights-based, and conceived of the family as a secular entity. They did not win support among Christian Democrats, and they were never debated in committee.

The first divorce bill, introduced in 1991, referred to individual rights guaranteed by the constitution and to the fraudulent system of annulments, and outlined a liberal divorce regime. It sought to guarantee divorce in cases of mutual consent, aggravated circumstances, and separation of the couple for more than one year. This bill garnered no support beyond the left. Two similar bills, introduced in 1993 and 1994, met the same fate.

Left representatives recognized that the only way to gain the necessary political support on an issue on which the church was solidly in 
opposition was to move away from rights-based rhetoric. This also required concessions on content to the extent that the 1995 bill was role-based (see table 3). Bill 1759 is qualitatively different from its predecessors in that it makes major concessions to conservatives and also reframes the issue as more "profamily"; that is, more role-based. The preservation of family unity as a general rule was the foundation of the new bill. For example, a mandatory five-year waiting period for a divorce was added to the bill, and judges were given broad powers to deny divorce requests.

Combining these provisions with the closing of the annulment loophole, the 1995 bill, in effect, made divorce much more difficult to come by than under the existing system, and this allowed Christian Democrats (and members of the right) to argue that the bill actually would strengthen the family. The bill's very title, the "New Civil Marriage Law," reflects efforts to avoid even the word divorce. As explained by Christian Democrat Ignacio Walker, one of the its sponsors, "It's not a divorce bill. It's a marriage bill" (Walker 2000). He explicitly rejected the idea of individual rights as justification for legal divorce. The bill was introduced by an alliance of liberal Christian Democrats and representatives from the left.

There are three distinct discourses behind the debate on the 1995 divorce bill. Despite these differences, each party makes an effort to link its support or opposition to Christian ethics and a desire to do what is best for the family. We can see a clear shift to role-based justifications in the discourse of the left in comparison to earlier attempts to justify divorce in terms of individual rights.

Representatives from the left portrayed the legislation as a practical and necessary solution to a glaring social problem, and elaborated their own ethically based argument, drawing on religion, to counter that of the right. As expressed by PPD Deputy Luis González, this position asserted that appeals to morality were hypocritical if they resulted in a continuation of the current social crisis.

If we continue to elude our obligation to legislate, we will condemn real men and women, of flesh and spirit, to live in bitterness and even in hate, and in danger as well. ... For these reasons, for Christian love toward concrete human beings, who suffer religious and social segregation due to a family situation that is irreparably broken, we [the parties of the left] agree with our votes to approve the present bill. (Chamber of Deputies 1997a)

The left also emphasized the pluralistic nature of Chilean society and the obligation of representatives to legislate for all Chileans, regardless of religion.

Those Christian Democrats who supported the divorce bill emphasized their strong support for the traditional institution of the family and 
asserted that the bill would strengthen rather than weaken the family, since it would replace the fraudulent annulment system. They also insisted that society must simultaneously promote the ideal of indissoluble marriage and address the social problems that result when people fail to live up to this ideal. PDC Deputy Mariana Aylwin explained that representatives'

\begin{abstract}
principal challenge consists in reconciling in our legislation a positive affirmation of marriage, and at the same time, searching for the best legal solution possible for irrevocable marital ruptures and new conjugal unions. . . . We don't consider this to be a contradiction, because it confirms as the norm that marriage is for life, admitting, nevertheless, that this norm can have exceptions. (Chamber of Deputies 1997b)
\end{abstract}

Most of the arguments by more conservative Christian Democrats against the divorce bill either reflected the reasoning of the Catholic Church (that is, that marriage is by nature indissoluble and that divorce would be an attack on the family) or directly cited the church's opposition. In public statements, newspaper editorials, and personal conversations with representatives, the highest-ranking leaders in the Chilean church insisted that Catholic legislators could not promote policies that contradicted church teaching. Archbishop Carlos Oviedo of Santiago explained, "a Catholic representative, if he wants to be true to his faith, cannot vote in favor of divorce" (Medina 1995, 2). Bishop Jorge Medina of Valparaíso affirmed more forcefully that "a Catholic must not ... favor any divorce law, defend it or support it. ... The Catholic cannot claim autonomy regarding material that involves the doctrine of the Church" (Medina 1995, 2). These sentiments were echoed in congressional debates by conservative Christian Democrats and representatives from the right. Christian Democrat Carlos Dupré, for example, exhorted his fellow representatives to vote against the divorce bill by asserting, "the Pope indicates that if we Catholics want to be true to our faith, we cannot defend and even less promote a divorce law. . . . There exists clear doctrine with regard to which the Christian cannot resort to the autonomy of his conscience" (Chamber of Deputies 1997c).

While conservative Christian Democrats were willing to defend their opposition to the bill on these grounds, the PDC's internal divisions on the issue created the possibility that a carefully negotiated bill could (and did) gain the support of enough Christian Democrats to pass the Chamber.

The right, by contrast, argued that divorce would have a detrimental effect on "average" women and children, who would lose the protection marriage provided them. For instance, RN Deputy Angelica Cristi argued that legal divorce would make it easier for spouses to abandon the home (El Mercurio 1997). 
After the bill passed in 1997, it was sent to the Senate, where it lay buried in a hostile Justice Committee until 2002. As noted, the factor that finally pushed it onto the Senate agenda was consistent executive pressure; Lagos had, during his presidential campaign, promised to push for legal divorce in Chile. Since assuming the presidency in 2000, he has gradually taken a more active stance and forced a Senate debate on an executive-modified version of the bill. The executive, SERNAM and the Ministry of Justice in particular, worked on updating the Chamber bill, making it easier in the executive version for couples to divorce on the basis of mutual consent and adding protections for children. While the final version allows for couples to file for divorce on the basis of mutual consent after a one-year separation, the judge will take another three years to process the filing, which includes a mandatory mediation process. Given the nature of these restrictions (forced counseling for separated couples in order to promote family unity), we continue to classify this version as role-based. This version was finally approved on the Senate floor in March 2004 and signed into law by the president on May 8, 2004.

\section{Rights-based, Class Bills}

Bills in this category are rights-based and also threaten class privileges; hence they are likely to provoke strong opposition. Class-based bills are more difficult to pass because economically conservative sectors in the Christian Democratic Party oppose them, and must be brought on board through negotiation on the bills' content, particularly those aspects of the bill perceived to be most threatening to class interests. Building such a consensus is especially difficult when the obvious focus of the bill is a defense of individual rights, in contrast to the defense of traditional social roles. In general, the strong support these bills enjoy from liberal Christian Democrats and the impossibility of framing opposition based on Catholic doctrine means that economically conservative Christian Democrats are not in a strong position to reject the proposals. If such a bill goes to the floor for debate, class-based opposition becomes increasingly public and, in the case of PDC representatives, increasingly difficult to defend. The right will try to bury the issue, but if the left succeeds in keeping the issue on the agenda, passage is likely. Only four bills, three of which are on paternity law, fall into this category (see table 6).

\section{Bills to Reform Paternity Laws}

Date of introduction: Bill 1060, 1993 (Executive proposal).

Fate: Passed the Chamber of Deputies in November 1994; Passed the Senate in 1998. 
Table 6. Rights-based, Class Bills

\begin{tabular}{llclll}
\hline \hline & Topic & Introduced & Sponsor & $\begin{array}{c}\text { Passed } \\
\text { Chamber }\end{array}$ & $\begin{array}{c}\text { Passed } \\
\text { Senate }\end{array}$ \\
\hline Bill 374 & Paternity laws & $6 / 11 / 91$ & $\begin{array}{l}\text { Congress: } \\
\text { Left }\end{array}$ & No & \\
Senate Bill & Paternity laws & $6 / 9 / 92$ & $\begin{array}{l}\text { Congress: } \\
\text { 719 }\end{array}$ & No & \\
Bill 1060 & Paternity laws & $8 / 10 / 93$ & SERNAM & Yes & Yes \\
Bill 1631 & Wage & $6 / 14 / 95$ & $\begin{array}{l}\text { Congress: } \\
\text { Left/PDC }\end{array}$ & No & \\
& discrimination & & Left & \\
\hline \hline
\end{tabular}

Support: Left: unanimous. PDC: resistance among conservative Christian Democrats, support by progressive Christian Democrats, final floor vote had unanimous PDC support. Right: strong resistance early on, but majority support in the final vote.

Discourse: Before the reform of paternity laws in Chile in 1998, fathers who failed to recognize their extramarital children had little responsibility to provide for the children's support. "Illegitimate" children were only entitled to the level of care "indispensable for sustaining life," and had a right to inheritance "only if there existed an express declaration in the father's will" (Chamber of Deputies 1994d).

Efforts to reform the paternity law centered on abolishing these distinctions in status-and parental responsibility-between children. At the time the bill was introduced, more than a third of Chilean children were born outside marriage (Cáceres et al. 1993; Centro de Estudios de la Mujer 1996). The issue of paternity is linked to women's rights in that fathers' lack of legal responsibility toward their extramarital children leaves single mothers solely responsible for their children's care and education. After earlier failed attempts by the left to pass a reform of paternity laws, a successful executive bill was introduced. A law abolishing these distinctions finally passed in September 1998, five years after its introduction in Congress.

During formal debate on the bill, representatives from the left to the right framed their arguments in terms of what was best for the family. In informal debate in committee, the prime objection of the conservative Christian Democrats and members of the right was to give extramarital children automatic rights to inheritance. In public debate, however, those Christian Democrats declared that lessening the stigma of children born outside of marriage would encourage out-of-wedlock births and undermine the institution of the family. 
By contrast, the left and progressive Christian Democrats argued that the proposed reforms would strengthen the family by making men less likely to father children outside of marriage and by making them more responsible for their extramarital children. Arguments by the left centered on the need for Chilean law to recognize and address the situation of citizens as they actually exist, and not according to what was perceived to be an artificial and narrow definition of the family. The comments of Socialist Deputy Juan Pablo Letelier typify this position.

Many times I ask myself if the majority of us Chileans suffer from schizophrenia or if we are hypocrites through and through, because we all know that the popular family, not through any lack of morality or ethics or religious beliefs, lives a different reality, and in addition [we know] this [other reality] is not limited to the popular sectors, but crosses all the sectors of our society. (Chamber of Deputies 1994e)

Liberal Christian Democratic representatives shied away from attacking the traditional model of the family as flawed, emphasizing instead social responsibility toward the weakest members of society. Mariana Aylwin argued,

Who can say that a single mother with children is not a family? I firmly believe, like the overwhelming majority of Chileans, that the ideal is a family based on marriage, and that this is possible. In fact, the majority does live this way, but it is blindness and injustice to leave defenseless those who live another reality. It amounts to accepting that the ends justify the means. (Chamber of Deputies 1994f)

In response, the right crafted an argument that explicitly prioritized the preservation of traditional definitions of the family over the individual rights of children. UDI Senator Carlos Bombal summarized the right's position.

As people, both types of children enjoy equal rights; but this is not the issue. It's not about the rights that correspond to children as individuals, but in consideration of them in relation to the institution that the very Constitution recognizes as fundamental in our society, that is to say the family, understood-it could not be otherwise-as that relationship which is born of the conjugal union of the spouses. (Senate 1997)

The relative ease with which concern for children can be linked to a concern for the family as a whole allowed the left to garner support from the Christian Democrats (including support from the Christian Democratic minister of SERNAM, who sponsored the third, successful paternity bill) and eventually from the right, for a bill that was both rights-based and threatening to class privileges. For their part, conservatives were unable to use Catholic teaching on the family to justify their 
opposition to the bill. The bill passed the Chamber of Deputies in only a year, but negotiations in the Senate, where conservative opposition was stronger, took four years. The bill finally passed in 1998.

\section{Pouicy INfluence Through STRATEgic Framing}

A study of women's rights legislation illuminates how values and ideology interact with institutional factors to impede or promote leftist influence over congressional policymaking. Chile's institutional structure, although powerful, creates incentives for cooperation as well as competition among parties, and the battle to reform laws on women's rights has been part of a larger struggle by the left to have an influence on legislative policy. Strategically framing its proposals on women's rights to reflect conservative perceptions of women's roles was a tactic that helped increase the left's ability to gain cross-party support for its proposals after 1994, as evidenced by the increase in cross-party support for bills at the point of introduction.

The empirical analysis of specific legislative proposals clarifies what abstract institutional or political "space" for negotiation means in terms of actual policy proposals. This study makes clear that in political negotiations on contentious social issues, political actors are constrained in ways not apparent from observation of institutional rules alone. In Chile, the Catholic Church is an important variable in determining the range of feasible policy options in the Concertación. The Christian Democratic Party's close links to the church limit the party's flexibility in policy negotiations, and therefore, left proposals that bring the coalition into conflict with the church will have a difficult time surviving the legislative process.

Yet this analysis also suggests that the limits of this ideological space are more flexible than might be expected, especially given the strength of conservative social and political forces in Chile. Strategic framing of policy proposals to reflect traditional conceptions of women and the family decreases the ability of conservative representatives to use Catholic discourse as a justification for opposition to reform. While "rolebased" framing may fail to win support for issues that directly contradict church teaching, as with the 1991 abortion bill, church opposition does not automatically doom a controversial proposal. The example of the 1995 divorce bill demonstrates that a strategically framed legislative proposal can succeed even though it conflicts with an official church position. In such cases, the left may have to make concessions on content.

Employing such a strategy, however, presents both short- and longterm political risks for proponents of women's equality. Legislative proposals on subjects ranging from expanding the availability of day care 
to legalizing divorce to facilitating women's access to safe abortion can be framed in ways that either challenge traditional conceptions of women's roles or embrace them. A given frame will affect the type of legislation passed and the degree to which the new law expands women's equality in practice. Adopting the traditional gender frames of congressional conservatives risks playing into the hands of those opposed to women's rights by legitimating their logic and discourse. In this way, long-term, more extensive changes may be sacrificed for shortterm expediency and political pragmatism.

Not recognizing women as independent individuals with equal rights undermines the consolidation of a democracy of formally equal citizens. The continuing need for the left-and politicians in general-to justify the enhancement of women's rights in role-based terms may be extreme in the case of Chile, but this dynamic in distinct forms is common across democratic countries where religion is politically influential.

\section{NoTES}

1. In Uruguay more specifically, it has allowed the country to maintain its liberal laws from an earlier era.

2. Church lobbying tactics included direct pressure on individual representatives, public statements against bills, and a visible presence in the congress during debates on the legislation. This characterization of the church's political activity since the transition may seem surprising to those more familiar with the church's pretransition work in defense of human rights; yet it is precisely the visibility and political legitimacy gained through this work that the church is now using to influence political debate on contentious social issues. In lobbying representatives whom the military government had persecuted, for example, church officials made particular reference to how the church had protected the democratic opposition during the dictatorship. In interviews, representatives commonly characterized this approach as the church's attempt to "collect on the bill" from its pro-human rights work under the dictatorship (for more detail on these points, see Haas 1999; Blofield 2001; Htun 2003).

3. For an analysis of how socioeconomic conditions in Chile-namely, inequality - have affected the relative strength of the church and conservatives, reformist mobilization, and left and right political agendas on moral issues, see Blofield 2003. In this analysis, the point of departure is the political level.

4. Magar et al. describe a similar dynamic in Chile's electoral campaigns, in which different parties from the Concertación must share the electoral list in many districts. Because of Chile's open-list electoral system, parties face "perverse incentives" to elect their own candidate from the list while simultaneously competing as a unified list against the opposing coalition.

5. A public opinion poll pegged support for legal divorce at 80 percent in 1996 (Desuc-Copesa 1996); another poll in 2002 found that 85 percent of Chileans favored legal divorce on grounds of mutual consent (FLACSO-Chile 2003). Public opinion polls also found majority support for legal abortion on 
therapeutic grounds and in cases of rape (Desuc-Copesa 1996; FLACSO-Chile 2003).

6. In the first democratic congress (1990-94), three self-identified feminists were elected from the parties of the left and none from the Christian Democrats or the right. In the second congress (1994-98), four self-identified feminists were elected from the left, one from the Christian Democrats, and none from the right. In the third congress (1998-2002), five self-identified feminists were elected from the left, two from the Christian Democrats, and none from the right.

7. In the specific case of Chile, Londregan (2000) identifies this as a "social dimension" on issues of personal morality.

8. One representative from the RN voted against; one UDI representative abstained.

9. For examples of public comments by politicians on abortion, see Haas 1999; Blofield 2001. In 1993, a coalition of feminist NGOs drafted a second bill on abortion but, mindful of the uproar caused by the 1991 bill, no representative would sponsor it.

10. Since 1991, the right has proposed three bills to increase penalties on abortion, one of which was defeated in the Senate in 1998 by two votes. The Concertación's opposition to this bill focused on class: poor women disproportionately suffer the legal consequences of clandestine abortions, given that wealthy women can afford safe and therefore "invisible" abortions. Although conservative Christian Democrats privately expressed support for the bill before the floor debate, once the debate was public they voted against it (Larraín 2001).

\section{REFERENCES}

Aguiló, Sergio. 2001. PS Senator. Interview by Haas. Santiago, June 4.

Baldez, Lisa. 2001. Coalition Politics and the Limits of State Feminism. Women and Politics 22, 4: 1-28.

Baldez, Lisa, and John M. Carey. 1999. Presidential Agenda Control and Spending Policy: Lessons from General Pinochet's Constitution. American Journal of Political Science 43: 29-55.

Blofield, Merike. 2001. The Politics of "Moral Sin": A Study of Abortion and Divorce in Catbolic Cbile Since 1990. Nueva Serie. Santiago: FLACSO.

- 2003. Inequality and Democratic Politics: The Catholic Church, Feminists, and Policy Reform on Abortion and Divorce in Chile, Argentina, and Spain. Ph.D. diss., Department of Political Science, University of North Carolina, Chapel Hill.

Cáceres, Ana, Isabel Cárcamo, Patricia Provoste, and Gloria Salazar. 1993. ¿Cómo les ba ido a las mujeres en la democracia? Santiago, Chile: Instituto de la Mujer.

Carey, John M. 2002. Parties, Coalitions, and the Chilean Congress in the 1990s. In Legislative Politics in Latin America, ed. Scott Morgenstern and Benito Nacif. New York: Cambridge University Press. 222-53.

Centro de Estudios de la Mujer. 1996. Educar o no educar . . . el dilemma de la educación sexual. Argumentos Para el Cambio 7 (September): 1-4. 
Chilean National Congress. Chamber of Deputies. 1991. Legislature 322, session 41a. Debate on Bill 499. Santiago: Congressional Record, September 17: 4087.

1994a. Legislature 329a, session 36a. Debate on Bill 1251. Testimony of Isabel Allende. September 6: 4011.

- 1994b. Legislature 329a, session 36a. Debate on Bill 1251. Testimony of PDC deputy. September 6: 4011.

- 1994c. Legislature 329a, session 36a. Debate on Bill 1251. Testimony of René García. September 6: 4011.

1994d. Legislature 329a, session 41. Debate on Bill 1060. September 15.

- 1994e. Legislature 329a, session 41. Debate on Bill 1060. Testimony of Deputy Juan Pablo Letelier. September 15: 4425.

- 1994f. Legislature 329a, session 41. Debate on Bill 1060. Testimony of Mariana Aylwin. September 15: 4425.

- 1997a. Legislature 334a, session 44a. Debate on Bill 1759. Testimony of Deputy Luis González. January 23.

-1997b. Legislature 334a, session 44a. Debate on Bill 1759. Testimony of Deputy Mariana Aylwin. January 22.

-1997c. Legislature 334a, session 44a. Debate on Bill 1759. Testimony of Deputy Carlos Dupré. January 22.

Chilean National Congress. Senate. 1994. Legislature 329, session 33a. Debate on Bill 19.408. Congressional Record, September 13: 4622.

- 1995. Legislature 330, session 32a. Debate on Bill 19.408. Testimony of Designated Senator William Thayer. January 4: 3525.

— 1997. Legislature 334a, session 24. Testimony of Senator Carlos Bombal. January 14: 4415.

Constable, Pamela, and Arturo Valenzuela. 1991. A Nation of Enemies: Chile Under Pinochet. New York: W. W. Norton.

Deininger, Klaus, and Lyn Squire. 1996. Measuring Income Inequality: A New Database. World Bank data set. <www.worldbank.org/research/growth/ dddeisqu.htm>

Desuc-Copesa. 1996. Public opinion survey, 1,980 cases. Santiago, November.

Esping-Andersen, Gøsta. 1990. The Three Worlds of Welfare Capitalism. Princeton: Princeton University Press.

Facultad Latinoamericana de Ciencias Sociales (FLACSO)-Chile. 2003. Percepciones y actitudes de las y los chilenos a principios del siglo XXI. Encuesta nacional de opinión pública. Public opinion survey. Representative sampling of all ten regions of Chile ( $84 \%$ of urban and $72 \%$ of rural population). 1,199 cases. Santiago, March.

Fleet, Michael, and Brian H. Smith. 1997. The Catbolic Cburch and Democracy in Chile and Peru. Notre Dame: University of Notre Dame Press.

Grau, Olga, Eugenia Brito, Riet Delsing, and Alejandra Farías, eds. 1997. Discurso, genero y poder: discursos públicos: Chile 1978-1993. Santiago: LOM-ARCIS.

Haas, Anna Liesl. 2000. Legislating Equality: Institutional Politics and the Expansion of Women's Rights in Chile. Ph.D. diss., University of North Carolina.

Haas, Liesl. 1999. The Catholic Church in Chile: New Political Alliances. In Latin American Religion in Motion, ed. Christian Smith and Joshua Prokopy. New York: Routledge. 43-66. 
Hinzpeter, Ximena, and Carla Lehmann. 1999. Las dos alas de la DC: la fuerte tensión interna del principal partido. Paper. Santiago: Centro de Estudios Públicos.

Hobson, Barbara, and Mieko Takahashi. 1997. The Parent-Worker Model: Lone Mothers in Sweden. In Lewis 1997.

Huber, Evelyne, and John D. Stephens. 2001. Development and Crisis of the Welfare State: Parties and Policies in Global Markets. Chicago: University of Chicago Press.

Htun, Mala. 2003. Sex and the State: Abortion, Divorce and the Family Under Latin American Dictatorships and Democracies. New York: Cambridge University Press.

Larraín, Hernán. 2001. UDI Senator, sponsor of 1998 abortion bill. Interview by Blofield. Santiago, January 14.

Lewis, Jane, ed. 1997. Lone Mothers in European Welfare Regimes: Shifting Policy Logics. Philadelphia: Jessica Kingsley.

Londregan, John B. 2000. Legislative Institutions and Ideology in Cbile. New York: Cambridge University Press.

Magar, Eric, Marc R. Rosenblum, and David Samuels. 1998. On the Absence of Centripetal Incentives in Double-Member Districts: The Case of Chile. Comparative Political Studies 31 (December): 714-39.

Matus, Veronica. 1997. Leader of La Morada feminist organization. Interview by Haas. Santiago, April 2.

Mazur, Amy G. 2002. Theorizing Feminist Policy. Oxford: Oxford University Press.

Medina, Jorge. 1995. De nuevo el tema del divorcio vincular. Valparaíso: Arzobispado de Valparaíso.

El Mercurio (Santiago). 1997. Dos bellas y audaces: las protagonistas de la gran disputa del RN. April 27: D22.

Molyneux, Maxine. 1985. Mobilization Without Emancipation? Women's Interests, the State, and Revolution in Nicaragua. Feminist Studies 11, 2: 227-54.

Muñoz, Adriana. 2001. PPD Deputy. Interview by Haas. Valparaíso, June 5.

Norton, Noelle H. 1999. Uncovering the Dimensionality of Gender Voting in Congress. Legislative Studies Quarterly 24, 1 (February): 656-86.

O'Connor, Julia S., Ann Shola Orloff, and Sheila Shaver. 1999. States, Markets, Families. Cambridge: Cambridge University Press.

Palma, Andrés. 1997. PDC Deputy. Interview by Haas. Santiago, May 12.

- 2001. Interview by Haas. Santiago, May 30.

Petras, James, and Fernando Ignacio Leiva. 1994. Democracy and Poverty in Chile: The Limits to Electoral Politics. Boulder: Westview Press.

Pickup, Francine. 2001. Ending Violence Against Women: A Cballenge for Development and Humanitarian Work. London: Oxfam.

Pollarolo, Fanny. 1997. PS Deputy. Interview by Haas. Santiago, January 15.

Roberts, Kenneth. 1998. Deepening Democracy: The Modern Left and Social Movements in Cbile and Peru. Stanford: Stanford University Press.

Saa, María Antonieta. 2001. PPD Deputy. Interview by Haas. Valparaíso, June 5. Sainsbury, Diane, ed. 1994. Gendering Welfare States. London: Sage.

- 1999. Gender and Welfare State Regimes, Oxford: Oxford University Press. 
Scully, Timothy. 1996. Chile: The Political Underpinnings of Economic Liberalization. In Constructing Democratic Governance: Soutb America in the 1990s, ed. Jorge I. Domínguez and Abraham I. Lowenthal. Baltimore: Johns Hopkins University Press. 99-117.

Sen, Amartya. 1999. Development as Freedom. New York: Knopf.

Siaroff, Alan. 1994. Work, Welfare and Gender Equality: A New Typology. In Sainsbury 1994. 82-100.

Siavelis, Peter M. 2002. Exaggerated Presidentialism and Moderate Presidents: Executive-Legislative Relations in Chile. In Legislative Politics in Latin America, ed. Scott Morgenstern and Benito Nacif. New York: Cambridge University Press. 79-113.

- 2000. The President and Congress in Postauthoritarian Chile: Institutional Constraints to Democratic Consolidation. University Park: Penn State Press.

Valenzuela, Maria Elena. 1997. Sociologist. Interview by Haas. Santiago, January 9.

—. 1999. El desafio de hacer política feminista desde el estado. mujer/fempress, edición especial.

Walker, Ignacio. 2000. PDC Deputy. Interview by Blofield. Santiago, September 11.

Waylen, Georgina. 1993. Women's Movements and Democratization in Latin America. Third World Quarterly 14, 3: 573-87.

1996. Women's Movements, the State and Democratization in Chile: The Establishment of SERNAM. In Getting Institutions Right for Women in Development, ed. Anne Marie Goetz. London: Zed Books. 90-103.

Weber, Paulina. 1997. Leader, Movement for the Emancipation of Chilean Women (MEMCH), feminist organization. Interview by Haas. Santiago, March 25. 